\title{
Radish cultivation with hydrogel doses combined with different water slides in drip irrigation system
}

\author{
Cultivo de rabanete com doses de hidrogel combinadas com diferentes lâminas de água em sistema \\ de irrigação por gotejamento \\ Cultivo de rábano con dosis de hidrogel combinado con diferentes láminas de agua en sistema de
}

riego por goteo

Received: 03/29/2021 | Reviewed: 04/08/2021 | Accept: 04/11/2021 | Published: 04/22/2021

Patricia dos Santos Zomerfeld

ORCID: https://orcid.org/0000-0001-8590-839X

Universidade Federal da Grande Dourados, Brazil

E-mail: patricia.zomerfeld@gmail.com

Natane Bonfim Lima

ORCID: https://orcid.org/0000-0003-0160-2567

Universidade Federal da Grande Dourados, Brazil

E-mail: natanebonfim@gmail.com

Guilherme Augusto Biscaro

ORCID: https://orcid.org/0000-0001-6907-2756

Universidade Federal da Grande Dourados, Brazil

E-mail: guilhermebiscaro@ufgd.edu.br

Anamari Viegas de Araujo Motomiya

ORCID: https://orcid.org/0000-0003-2170-8676

Universidade Federal da Grande Dourados, Brazil

E-mail: anamarimotomiya@ufgd.edu.br

Aline Baptista Borelli

ORCID: https://orcid.org/0000-0002-5197-7909

Universidade Federal da Grande Dourados, Brazil

E-mail: alineborelly@hotmail.com

Kamila de Almeida Monaco-Mello

ORCID: https://orcid.org/0000-0002-6118-2640

Universidade Federal da Grande Dourados, Brazil

E-mail: kamilamonaco@ufgd.edu.br

Maximiliano Kawahata Pagliarini

ORCID: https://orcid.org/0000-0001-7408-6327

Universidade Federal da Grande Dourados, Brazil

E-mail: mpagliarini@ufgd.edu.br

\begin{abstract}
Radish yield and quality are factors influenced by water stress that may occur during periods of drought or irrigation handled inappropriately, interfering negatively in plants development, producing radishes of inferior quality and in lesser quantity. In addition to irrigation, which makes water available in the system, it is important to maintain it with the use of water-retaining products such as hydrogel. The aim of this work was to evaluate radish yield, submitted to three different hydrogel doses combined with two water slides. The experimental design was in factorial scheme $3 \times 2$, with three water slides $(50 \%, 75 \%$ and $100 \%$ Eto - reference evapotranspiration estimate) and two hydrogel doses (40 and $60 \mathrm{~g} \mathrm{~m}^{-2}$ ) with four replicates. Number of leaves, horizontal and vertical root diameter (mm), total and shoot length $(\mathrm{cm})$, fresh mass of root and shoot $(\mathrm{g})$, dry mass of shoot and root $(\mathrm{g})$ and yield $\left(\mathrm{t} \mathrm{ha}^{-1}\right)$ were evaluated. The best results, regarding radish production and development, were obtained when using $50 \%$ of Eto with $60 \mathrm{~g} \mathrm{~m}^{-2}$ of hydrogel in combination. Thus, radish cultivation in oxisoil was influenced by the use of hydrogel, which provided a more efficient water level use.
\end{abstract}

Keywords: Drip irrigation; Water-retaining polymer; Raphanus sativus L.

\section{Resumo}

A produtividade e a qualidade do rabanete são fatores influenciados pelo estresse hídrico que pode ocorrer por períodos de seca ou por irrigações manejadas de forma inadequada, interferindo negativamente no desenvolvimento das plantas, produzindo rabanetes de qualidade inferior e em menor quantidade. Além da irrigação, que disponibiliza a água no sistema, é importante mantê-la com o uso de produtos hidrorretentores como o hidrogel. O objetivo deste trabalho foi avaliar a produtividade do rabanete, submetido a combinações de três diferentes doses de hidrogel com 
duas lâminas de água na irrigação. O delineamento experimental foi em esquema fatorial 3 x 2, sendo três lâminas de irrigação (50\%, 75\% e 100\% da Eto - estimativa da evapotranspiração de referência) e duas doses de hidrogel (40 e $60 \mathrm{~g} \mathrm{~m}^{-2}$ ) com quatro repetições. Foram avaliados o número de folhas, diâmetro horizontal e vertical da raiz (mm), comprimento total e da parte aérea $(\mathrm{cm})$, massa fresca da raiz e da parte aérea $(\mathrm{g})$, massa seca da raiz e da parte aérea (g) e a produtividade $\left(\mathrm{t} \mathrm{ha}^{-1}\right)$. Os melhores resultados, em relação à produção e ao desenvolvimento do rabanete foram obtidos quando se utilizou a combinação de $50 \%$ da Eto com $60 \mathrm{~g} \mathrm{~m}^{-2}$ de hidrogel. Assim, o cultivo de rabanete em latossolo vermelho distroférrico foi influenciado pelo uso de hidrogel, o qual proporcionou um uso mais eficiente das lâminas de água.

Palavras-chave: Irrigação por gotejamento; Polímero hidrorretentor; Raphanus sativus L.

\section{Resumen}

La productividad y calidad del rábano son factores influenciados por el estrés hídrico que puede ocurrir durante períodos de sequía o regadíos manejados de manera inadecuada, interfiriendo negativamente en el desarrollo de las plantas, produciendo rábanos de calidad inferior y en menor cantidad. Además del riego, que hace que el agua esté disponible en el sistema, es importante mantenerlo con el uso de productos de retención de agua como el hidrogel. El objetivo de este trabajo fue evaluar la productividad del rábano, sometido a combinaciones de tres dosis diferentes de hidrogel con dos láminas de agua en riego. El diseño experimental fue en un esquema factorial 3 x 2, con tres láminas de riego (50\%, 75\% y 100\% de Eto - estimación de evapotranspiración de referencia) y dos dosis de hidrogel (40 y 60 $\mathrm{g} \mathrm{m}^{-2}$ ) con cuatro repeticiones. Se evaluó el número de hojas, diámetro horizontal y vertical de la raíz (mm), longitud total y parte aérea $(\mathrm{cm})$, peso fresco de la raíz y parte aérea $(\mathrm{g})$, masa seca de la raíz y parte aérea $(\mathrm{g})$ y productividad $\left(\mathrm{t} \mathrm{ha}^{-1}\right)$. Los mejores resultados, en relación a la producción y desarrollo del rábano, se obtuvieron cuando se utilizó la combinación de $50 \%$ de Eto con $60 \mathrm{~g} \mathrm{~m}^{-2}$ de hidrogel. Así, el cultivo de rábano en oxisol fue influenciado por el uso de hidrogel, que proporcionó un uso más eficiente de las láminas de agua.

Palabras clave: Riego por goteo; Polímero que retiene el agua; Raphanus sativus L.

\section{Introduction}

The radish (Raphanus sativus L.) is a small-sized plant belonging to Brassicacea family, which in cultivars of greater acceptance, produces globular roots, of bright scarlet colour and white pulp (Filgueira, 2005). The globular root is edible, containing medicinal properties as a stimulant of digestive system and natural expectorant. It also has vitamins A, C, B1, B2, B6, potassium, folic acid and calcium, it has antioxidant activity, low amount of calories and high amount of dietary fibre (Camargo et al., 2007). It is a crop of rapid economic return for rural producers, due to its short cycle, around 30 days. Although it represents a low planted area, it is an important option for small properties which form the green belts (Linhares et al., 2010).

In addition to small areas intended for radish production, yield and root quality are influenced by periods of drought or by inappropriately irrigation (Kang \& Wan, 2005), thus, temperature variations and soil moisture, during plant development, may impair productivity and the quality of final product.

The water factor is one of the major limits in the development and production of any crop, after all, water is present in all plant compositions, either morphologically or physiologically, so water stress is harmful. Therefore, offering water to plants in dry seasons may increase yield and product quality. According to Oliveira et al. (2020), water is the most important element in agriculture and has made significant contribution, providing stability in food production.

Specifically for horticultural species, irrigation is almost mandatory as plants are very sensitive to water stress, but the quantity of water needs to be well dosed, just as lack may be harmful, the excess also causes losses, mainly by root system rotting. Therefore, the application of water slides in adequate amount and moment is fundamental for irrigated cultivation success. For that, it is necessary to adopt irrigation management techniques that help in the best decision making, especially to the adequate irrigation management.

It is worth mentioning that agricultural productivity in irrigated systems is directly related to the uniformity of water distribution to plants. Periodically assessing this water distribution is essential, as the irregularity of this parameter may cause waste of water, energy and money (Santos et al., 2017). 
Andrade et al. (2021) reported that irrigation efficiency is a widely used concept, both in projects and in the management of irrigation systems. For efficient irrigation, it is imperative that systems exhibit high uniformity of water application. Once an irrigation project is installed, it is necessary to check if the conditions initially foreseen are confirmed in field. For this, the conditions of depression, flow and water slides applied must be evaluated. In addition to this, it is important to mention that each crop has a specifically necessity, therefore researches are need to be done.

In drip irrigation system, the emitter responsible for the application of water is the dripper, which, according to Salomão (2012), applies water to the soil in drops, at one point and directly over plant root zone with small flows. The drippers according to Bernardo et al. (2006) are the main parts of the drip irrigation system, their function is to dissipate the pres sure available on the lateral line and apply small and constant flows.

The main advantage of this system is water savings, as irrigation is performed in a localized way on a constant drop by drop form. This way, there will never be lack or waste of water, as the system will not irrigate adjacent areas.

Introducing water into the system, by irrigation systems is important, as seen previously, however, maintaining it is also fundamental. In very warm places, even when irrigation is performed at milder temperatures times, the loss of water to the atmosphere will also be constant. Therefore, it is necessary to find alternatives that make water continue in soil.

The recommended practice for estimating these water losses is by crop evapotranspiration (ETc) which is based on reference evapotranspiration values (ETo), which are determined locally using weather station data and crop coefficient (Kc) values, determined experimentally in field in certain local conditions by means of lysimeters for each crop (Faria et al., 2006; Fenner et al., 2019; Daniel et al., 2020).

Evapotranspiration is defined as the loss of water to the atmosphere, in which there is a simultaneous occurrence of transpiration and evaporation processes (Allen et al., 1998). In transpiration, the plant uses the water contained in the soil and, through leaf physiological structures, such as stomata, this water is transferred in vapour form to the atmosphere (Lago et al., 2011). Evaporation is the removal of water from the soil into the atmosphere (Dalmago et al., 2010).

Considering the need to increase production in view of the scarcity of water resources, the search for alternatives to optimize production in regions that face water deficits is mandatory. In this sense, the use of water-retaining polymers, hydrogels, may be interesting, as they act as regulators of water availability for crops, increasing local productivity and minimizing production costs (Mendonça et al., 2013).

Hydrogels may be defined as three-dimensional structures formed from interlocking hydrophilic macromolecules or polymers that, when absorbing water, even in large quantities, are able to maintain their structure without undergoing dissolution (Venturoli \& Venturoli, 2011).

The use of hydrogels in agriculture has been a strategy for agricultural management, due to its characteristics of soil conditioners that contribute to increase the capacity of water retention in soil, reducing the irrigation frequency, because their release occurs in a continuous flow, in the necessary amount for plants development (Venturoli \& Venturoli; Rehman et al., 2011).

Several works were developed from the 1980s onwards to study hydrogels as soil conditioners, mainly as products capable of retaining and making water available for agricultural crops (Willingham Jr. et al., 1981; Wallace, 1987; Sayed et al., 1991). Since then, it has been found that the application of hydrogels to the soil or substrate increases water retention, reduces nutrient losses through percolation and leaching, improves soil aeration and drainage, resulting in positive effects on seedling growth,-survival and productivity of cultures (Yonezawa et al., 2017; Melo et al., 2019; Nomura et al., 2019; Demartelaer et al., 2020).

Thus, the objective of this study was to evaluate radish yield submitted to different combinations of doses of waterretaining polymer (hydrogel) and water slides in drip irrigation. 


\section{Methodology}

The experiment was conducted in the municipality of Dourados, Mato Grosso do Sul state, at the Faculty of Agrarian Sciences (FCA) of the Federal University of Grande Dourados. The average local altitude is $446 \mathrm{~m}$, with latitude $22^{\circ} 11$ ' $45^{\prime}$ ' S and longitude $54^{\circ} 55^{\prime} 18^{\prime \prime} \mathrm{W}$.

The soil in the experimental area was classified as Oxisoil, according to classification of Embrapa (2013) and its fertility may be seen in Table 1 .

Table 1. Chemical analysis of soil in the experimental area.

\begin{tabular}{|c|c|c|c|c|c|c|c|c|c|c|}
\hline \multirow{2}{*}{ Depth (m) } & \multirow{2}{*}{$\mathbf{p H}^{*}$} & $\mathbf{P}$ & O.M.** & $\mathbf{K}$ & $\mathbf{C a}$ & Mg & H+Al & $\mathbf{S}$ & $\mathbf{T}$ & $\mathbf{V}$ \\
\hline & & \multicolumn{2}{|c|}{$\mathrm{g} \mathrm{dm}^{-3}$} & \multicolumn{6}{|c|}{ 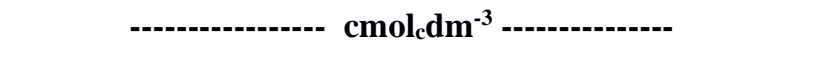 } & $\%$ \\
\hline $0.0-0.2$ & 4.9 & 9.73 & 21.45 & 0.30 & 6.83 & 2.42 & 6.69 & 9.55 & 12.23 & 58.80 \\
\hline $0.2-0.4$ & 5.3 & 8.06 & 19.18 & 0.32 & 8.90 & 3.10 & 5.35 & 12.32 & 17.67 & 69.70 \\
\hline
\end{tabular}

${ }^{*} \mathrm{pH}$ in $\mathrm{CaCl} 2$ | ${ }^{* *}$ Organic matter content. Source: Authors.

The area was prepared 30 days before sowing, with soil plowing and harrowing. The cleaning of the area consisted of weeds elimination. At 10 days before sowing plats were made at soil to radish cultivation.

The experimental design was a randomized block design, in a $3 \times 2$ factorial scheme, with three water slides and two doses of hydrogel with four replications.

The doses used were 40.00 and $60.00 \mathrm{~g} \mathrm{~m}^{2}$. The hydrogel used had the technical specifications described in table 2 .

Table 2. Specifications of hydrogel used in radish cultivation in the experimental area. CEC: Cation exchange capacity; WRC: Water Retention Capacity

\begin{tabular}{ccccc}
\hline COMPOSITION & $\begin{array}{c}\text { CEC } \\
\left(\mathbf{m m o l}_{\mathbf{~}} \mathbf{~ d m}^{-3}\right)\end{array}$ & $\begin{array}{c}\text { WRC } \\
(\boldsymbol{\%})\end{array}$ & $\begin{array}{c}\text { PHYSICAL } \\
\text { NATURE }\end{array}$ & $\begin{array}{c}\text { SOIL } \\
\text { CONDITIONER }\end{array}$ \\
\hline $\begin{array}{c}\text { Copolymer } \\
\text { Polyacrylic Potassium Polyacrylamide }\end{array}$ & 532.26 & $1,526.69$ & Bran & Class E \\
\hline
\end{tabular}

Source: Created by authors according to producer specifications.

In relation to irrigation management, it was performed daily through the reference evapotranspiration estimate (Eto), based on the Penman-Monteith method according to Allen et al., (1998) (Equation 1).

$$
\mathrm{ETo}=\frac{0,408 \Delta(\mathrm{Rn}-\mathrm{G})+\gamma\left(\frac{900 \mathrm{U}_{2}}{\mathrm{~T}+273}\right)(\mathrm{es}-\mathrm{ea})}{\Delta+\gamma\left(1+0,34 \mathrm{U}_{2}\right)}
$$

Where, Eto: reference evapotranspiration $\left(\mathrm{mm} \mathrm{dia}^{-1}\right)$, Rn: liquid radiation $\left(\mathrm{MJ} \mathrm{m}^{-2} \mathrm{day}^{-1}\right)$; G: heat flow in the soil (MJ $\mathrm{m}^{-2}$ day $\left.^{-1}\right) ; \Delta$ : declination of the water vapour saturation curve $\left(\mathrm{kPa}^{\circ} \mathrm{C}^{-1}\right) ; \mathrm{U}_{2}$ : average wind speed at $2 \mathrm{~m}$ above the ground surface $\left(\mathrm{m} \mathrm{s}^{-1}\right)$; T: average air temperature $\left({ }^{\circ} \mathrm{C}\right)$; (es - ea): vapour pressure deficit $(\mathrm{kPa}) ; \gamma$ : psychometric constant $\left(\mathrm{kPa}^{\circ} \mathrm{C}^{-1}\right)$. 
The data were obtained from the Automated Meteorological Station Dourados-A721 (INMET), latitude -22¹1'34", longitude $-54^{\circ} 54^{\prime} 41^{\prime \prime}$. The management of irrigation was performed by means of water balance, and slides used to conduct the experiment were $50 \%, 75 \%$ and $100 \%$ of Eto.

The hydrogel doses application in the soil was performed three days before sowing, with the product not hydrated, and its incorporation was done by rakes to homogenize the product. After incorporation and preparation of plats, the irrigation system was installed using drip type (Petroísa brand, Manari model) with hoses spaced $30 \mathrm{~cm}$ apart and drippers spaced $20 \mathrm{~cm}$ apart. After installation, the water slides were applied, in sufficient quantity to hydrate the hydrogel doses.

Immediately after moistening the soil already prepared with water slides and hydrogel doses, the radish (Early Scarlet Globe variety) was sown directly. Pits with $3 \mathrm{~mm}$ deep were opened a distance of $30 \mathrm{~cm}$ between rows and $0.05 \mathrm{~cm}$ in the row, and in each pit were placed to germinate two to three seeds. After complete germination, thinning was performed to grow only one plant per pit.

Three lines of plants were used, each plot was constituted of 40 plants, the ten central plants were measured 44 days after sowing. The following variables were evaluated: number of leaves (NL), length of shoot part (LSP $-\mathrm{cm}$ ), total length (TL $-\mathrm{cm}$ ), vertical (VD) and horizontal (HD) diameter of roots (cm), fresh mass of shoot (FMS $-\mathrm{g}$ ), fresh mass of root (FMR $\mathrm{g}$ ), dry mass of shoot (DMS $-\mathrm{g}$ ), dry mass of root (DMR $-\mathrm{g}$ ) and yield $\left(\mathrm{t} \mathrm{ha}^{-2}\right)$. To assess measurements, it was used an electronic caliper to measure the diameter of roots, a metric ruler to measure height and precision analytical balance to determined fresh and dry masses.

The dry mass of shoot and root were defined after determining the fresh mass of their respective parts, when samples were packed in labelled paper bags and placed to dry in an oven with forced air circulation at temperature of $65^{\circ} \mathrm{C}$ until they reached constant masses.

Yield was estimated according to equation 2.

$$
\text { Yield }=\frac{\text { Averageof } 10 \text { usefulplants }(t) * 1 \text { ha }}{\text { usefularea }}
$$

Where: Useful area: corresponds to $0.15 \mathrm{~m}^{2}$ or $15 \times 10^{-4}$ ha.

For statistical analysis, software Assistat 7.7 was used. The effect of treatments and the relationship between the variables were evaluated by means of analysis of variance, verifying the significance by $F$ test. When significant (5\%), the Tukey test was performed for means comparison (Silva, 2012).

\section{Results and Discussion}

The different irrigation slides provided significant effects on radish development when compared to effects provided only by the hydrogel doses. In contrast, the interaction between irrigation slides and hydrogel doses, provided very relevant effects in this crop, mainly for parameters related to yield (Table 3). 
Table 3. Analysis of variance summary with $\mathrm{F}$ test and coefficient of variation of evaluated variables means during radishes characterization.

\begin{tabular}{|c|c|c|c|c|c|}
\hline FACTORS & NL & LSP & TL & HD & VD \\
\hline Irrigation slides (IS) & $19.28 * *$ & $31.47 * *$ & $38.40 * *$ & $40.14 * *$ & $41.03 * *$ \\
\hline Hydrogel doses (HD) & $1.26^{\mathrm{ns}}$ & $4.70^{*}$ & $5.04 *$ & $0.38^{\mathrm{ns}}$ & $3.30^{\mathrm{ns}}$ \\
\hline IS $x$ HD & $1.26^{\mathrm{ns}}$ & $3.63 *$ & $5.50 *$ & $4.76 *$ & $5.58 *$ \\
\hline Means & 6.97 & 12.40 & 15.64 & 30.92 & $9, .37$ \\
\hline $\mathrm{CV}(\%)$ & 6.79 & 8.46 & 8.13 & 9.75 & 33.42 \\
\hline FACTORS & FMS & FMR & DMS & DMR & Yield \\
\hline Irrigation slides (IS) & $42.06 * *$ & $47.66 * *$ & $37.45 * *$ & $77.89 * *$ & $47.37 * *$ \\
\hline Hydrogel doses (HD) & $2.14^{\mathrm{ns}}$ & $3.32^{\mathrm{ns}}$ & $2.71^{\mathrm{ns}}$ & $11.97 * *$ & $3.31^{\mathrm{ns}}$ \\
\hline IS x HD & $4.74 *$ & $10.91 * *$ & $3.08^{\mathrm{ns}}$ & $21.72 * *$ & $10.78 * *$ \\
\hline Means & 6.65 & 17.84 & 0.72 & 0.97 & 1.19 \\
\hline $\mathrm{CV}(\%)$ & 19.54 & 20.86 & 19.63 & 16.34 & 20.92 \\
\hline
\end{tabular}

** Significant at $1 \%$ probability level $(\mathrm{p}<0.01)$; Significant at $5 \%$ probability level $(0.01 \leq \mathrm{p}<0.05)$; ${ }^{\mathrm{ns}}$ not significant $(\mathrm{p} \geq 0.05)$. NL: number of leaves; LSP: length of shoot part; TL: total length; HD: horizontal diameter; VD: vertical diameter; FMS: fresh mass of shoot; FMR: fresh mass of root; DMS: dry mass of shoot; DMR: fresh mass of root; $\mathrm{CV} \%=$ Coefficient of variation in percentage. Source: Authors.

The use of hydrogel as a soil conditioner in radish cultivation provided better efficiency in irrigation water use, with the best responses obtained in cultivated plants with 50\% Eto slide, as reported in Table 4. Navroski et al. (2014), studying the influence of water-retaining polymer on the survival of Eucalyptus dunnii seedlings under different water managements, observed that the water-retaining polymer enables the delay of water deficit symptoms in Eucalyptus dunnii seedlings, with greater influence when irrigation was performed less frequently.

Table 4. Effect of three different water slides (100, 75 and 50\%) on number of leaves, length of shoot part; total length; horizontal diameter; vertical diameter; fresh mass of shoot; fresh mass of root; dry mass of shoot; fresh mass of root and yield of radish cultivated in different doses of hydrogel.

\begin{tabular}{|c|c|c|c|c|c|}
\hline Irrigation slides (IS) - \% & NL & $\mathbf{L S P}(\mathbf{c m})$ & TL $(\mathbf{c m})$ & HD (cm) & VD $(\mathbf{c m})$ \\
\hline 100 & $6.1 \mathrm{~b}$ & $10.3 \mathrm{c}$ & $12.7 \mathrm{c}$ & $23.5 \mathrm{c}$ & $25.0 \mathrm{~b}$ \\
\hline 75 & $7.3 \mathrm{a}$ & $12.6 \mathrm{~b}$ & $16.0 \mathrm{~b}$ & $32.5 b$ & $35.0 \mathrm{a}$ \\
\hline 50 & $7.5 \mathrm{a}$ & $14.4 \mathrm{a}$ & $18.2 \mathrm{a}$ & $36.7 \mathrm{a}$ & $39.0 \mathrm{a}$ \\
\hline Irrigation slides (IS) - \% & FMS (g) & FMR $(g)$ & DMS (g) & DMR (g) & Yield $\left(\mathbf{t} \mathbf{h a}^{-1}\right)$ \\
\hline 100 & $3.6 \mathrm{c}$ & $7.9 \mathrm{c}$ & $0.4 \mathrm{c}$ & $0.4 \mathrm{c}$ & $0.5 \mathrm{c}$ \\
\hline 75 & $6.9 \mathrm{~b}$ & $19.0 \mathrm{~b}$ & $0.8 b$ & $1.1 \mathrm{~b}$ & $1.3 \mathrm{~b}$ \\
\hline 50 & $9.5 \mathrm{a}$ & $25.0 \mathrm{a}$ & $1.0 \mathrm{a}$ & $1.4 \mathrm{a}$ & $1.7 \mathrm{a}$ \\
\hline
\end{tabular}

Means followed by the same uppercase (lines) and lowercase (columns) letters do not differ statistically according to the Tukey test ( $\mathrm{p} \geq$ 0.05). NL: number of leaves (NL); LSP: length of shoot part; TL: total length; HD: horizontal diameter; VD: vertical diameter; FMS: fresh mass of shoot; FMR: fresh mass of root; DMS: dry mass of shoot; DMR: fresh mass of root. Source: Authors. 
Zonta et al. (2009) and Moraes et al. (2001) affirmed that plants cultivated in clay soils have better agronomic development in low hydrogel doses, when compared to those grown in sandy soils. However, in the present study, the use of the maximum hydrogel dose, $60 \mathrm{~g} \mathrm{~m}^{-2}$, provided the highest averages for shoot length, total length and dry mass of root, which may be seen in Table 5 .

Table 5. Effect of 40 and $60 \mathrm{~g} \mathrm{~m}^{-2}$ of hydrogel on length of shoot part; total length and fresh mass of root of radish crop.

\begin{tabular}{cccc}
\hline Hydrogel doses $(\mathbf{g})$ & LSP $(\mathbf{c m})$ & TL $(\mathbf{c m})$ & DMR (g) \\
\hline $\mathbf{6 0}$ & $12.87 \mathrm{a}$ & $16.22 \mathrm{a}$ & $1.09 \mathrm{a}$ \\
$\mathbf{4 0}$ & $11.94 \mathrm{~b}$ & $15.06 \mathrm{~b}$ & $0.86 \mathrm{~b}$
\end{tabular}

Means followed by the same lower case letters (columns) do not differ statistically according to the Tukey test (* $p \geq 0.05) .:$ LSP: length of shoot part; TL: total length; DMR: fresh mass of root. Source: Authors.

As for traits that give commercial value to crop, the interaction of hydrogel doses with water slides provided significant differences for fresh mass of shoot, fresh and dry mass of the root and yield (Table 6). Unlike Oliveira et al. (2014), who studied the productive aspects of radish grown in dystrophic Red Latosol as a function of nitrogen fertilization with and without hydrogel, except for radish diameter, hydrogel did not influence the leaf length characteristics, number of leaves, total fresh mass, fresh mass of shoot, fresh mass of root.

Table 6. Effect of the interaction of hydrogel doses $\left(40\right.$ and $\left.60 \mathrm{~g} \mathrm{~m}^{-2}\right)$ and irrigation water slides $(50,75$ and 100\%) on fresh mass of shoot; fresh mass of root; fresh mass of root; and on radish yield.

\begin{tabular}{|c|c|c|c|c|}
\hline \multirow{3}{*}{ Irrigation slides (IS) - \% } & \multicolumn{4}{|c|}{ Hydrogel doses (g) } \\
\hline & \multicolumn{2}{|c|}{ FMS (g) } & \multicolumn{2}{|c|}{ FMR (g) } \\
\hline & 60 & 40 & 60 & 40 \\
\hline 100 & $3.62 \mathrm{cA} *$ & $3.49 \mathrm{bA}$ & $8.53 \mathrm{cA}$ & $7.39 \mathrm{bA}$ \\
\hline 75 & $6.47 \mathrm{bA}$ & $7.29 \mathrm{aA}$ & $17.19 \mathrm{bA}$ & $22.18 \mathrm{aA}$ \\
\hline 50 & $11.01 \mathrm{aA}$ & $7.99 \mathrm{aB}$ & $31.92 \mathrm{aA}$ & $19.77 \mathrm{aB}$ \\
\hline \multirow{2}{*}{ Irrigation slides (IS) - \% } & \multicolumn{2}{|c|}{ DMR (g) } & \multicolumn{2}{|c|}{ Yield $\left(t\right.$ ha $\left.^{-1}\right)$} \\
\hline & 60 & 40 & 60 & 40 \\
\hline 100 & $0,47 \mathrm{cA}$ & $0.39 \mathrm{bA}$ & $0.57 \mathrm{cA}$ & $0.50 \mathrm{bA}$ \\
\hline 75 & $1,13 \mathrm{bA}$ & $1.17 \mathrm{aA}$ & $1.15 \mathrm{bA}$ & $1.48 \mathrm{aA}$ \\
\hline 50 & $1,67 \mathrm{aA}$ & $1.05 \mathrm{aB}$ & $2.13 \mathrm{aA}$ & $1.32 \mathrm{aB}$ \\
\hline
\end{tabular}

Means followed by the same uppercase (lines) and lowercase (columns) letters do not differ statistically according to the Tukey test ( $\mathrm{p} \geq$ 0.05). FMS: fresh mass of shoot; FMR: fresh mass of root; DMR: fresh mass of root. Source: Authors.

The combination of $50 \%$ of Eto with $60 \mathrm{~g} \mathrm{~m}^{-2}$ of hydrogel attributed higher averages for these characteristics with plant presenting $11.01 \mathrm{~g}$ of fresh mass of shoot, $31.92 \mathrm{~g}$ and $1.67 \mathrm{~g}$ of fresh and dry mass of the root, respectively, and yield of $2.13 \mathrm{t} \mathrm{ha}^{-1}$ (Table 6). Santos et al. (2015) studying the cultivation of lettuce in soils with hydrogel using automated irrigation found that the use of hydrogel enabled greater efficiency in the use of water in the protected cultivation of lettuce.

This same trend, of the highest means being provided by the combination of $50 \%$ of Eto with $60 \mathrm{~g} \mathrm{~m}^{-2}$ of hydrogel, was observed for horizontal diameter $(39.49 \mathrm{~cm})$, vertical diameter $(42.82 \mathrm{~cm})$, total length $(20.00 \mathrm{~cm})$ and length of shoot part $(15.68 \mathrm{~cm})$, as demonstrated in Table 7. 
Table 7. Effect of the interaction of hydrogel doses (40 and $60 \mathrm{~g} \mathrm{~m}^{-2}$ ) and irrigation water slides (50, 75 and $\left.100 \%\right)$ on horizontal diameter; vertical diameter; total length and length of shoot part of redish.

\section{Hydrogel doses (g)}

\begin{tabular}{|c|c|c|c|c|}
\hline \multirow{3}{*}{ Irrigation slides (IS) - \% } & \multirow{2}{*}{\multicolumn{2}{|c|}{ HD $(\mathbf{c m})$}} & \multirow{2}{*}{\multicolumn{2}{|c|}{ VD (cm) }} \\
\hline & & & & \\
\hline & 60 & 40 & 60 & 40 \\
\hline 100 & $23.75 \mathrm{cA}$ & $23.26 \mathrm{bA}$ & $26.61 \mathrm{cA}$ & $24.27 \mathrm{bA}$ \\
\hline 75 & $30.65 \mathrm{bA}$ & $34.40 \mathrm{aA}$ & $34.32 \mathrm{bA}$ & $37.24 \mathrm{aA}$ \\
\hline \multirow[t]{2}{*}{50} & $39.49 \mathrm{aA}$ & $33.95 \mathrm{aB}$ & $42.82 \mathrm{aA}$ & $35.26 \mathrm{aB}$ \\
\hline & \multicolumn{2}{|c|}{ TL $(\mathbf{c m})$} & \multicolumn{2}{|c|}{$\mathbf{L S P}(\mathbf{c m})$} \\
\hline Irrigation slides (IS) - \% & 60 & 40 & 60 & 40 \\
\hline 100 & $12.75 \mathrm{cA}$ & $12.60 \mathrm{bA}$ & $10.32 \mathrm{cA}$ & $10.17 \mathrm{bA}$ \\
\hline 75 & $15.91 \mathrm{bA}$ & $16.16 \mathrm{aA}$ & $12.58 \mathrm{bA}$ & $12.51 \mathrm{aA}$ \\
\hline 50 & $20.00 \mathrm{aA}$ & $16.41 \mathrm{aB}$ & $15.68 \mathrm{aA}$ & $13.12 \mathrm{aB}$ \\
\hline
\end{tabular}

Means followed by the same uppercase (lines) and lowercase (columns) letters do not differ statistically according to the Tukey test ( $\mathrm{p} \geq$ 0.05). HD: horizontal diameter; VD: vertical diameter; TL: total length; LSP: length of shoot part. Source: Authors.

\section{Conclusion}

The cultivation of radish in oxisoil was influenced by the use of hydrogel. The application of hydrogel allowed more efficient use of water slides. The best results, in relation to radish production and development were obtained when using a combination of $50 \%$ of Eto with $60 \mathrm{~g} \mathrm{~m}^{-2}$ of hydrogel was used.

\section{References}

Allen, R. G., Pereira, L. S., Raes, D. \& Smith, M. (1998). Crop Evapotranspiration: guidelines for computing crop requirements. FAO.

Andrade, A. R. S. de, Silva, E. G. da, Silva, E. T. da, Pereira, R. G., Silva, J. F. da, Costa, C. M., Zamora, V. R. O., Cruzb, A. F. da S., Ferreira, M. E. da S., Silva, M. G. dos S., \& Noronha, D. A. de. (2021). Avaliação do desempenho de sistema de irrigação por gotejamento em cultivo de maracujá. Research, Society and Development, 10(4), e21710414034. https://doi.org/10.33448/rsd-v10i4.14034.

Bernardo, S., Soares, A. A. \& Mantovani, E. C. (2006). Manual de irrigação. UFV.

Camargo, G. A., Consoli, L., Lellis, I. C. S., Mieli, J. \& Sassaki, E. K. (2007). Bebidas naturais de frutas perspectivas de mercado, componentes funcionais e nutricionais. Revista Brasileira de Engenharia de Biossistemas, 1(2), 181-195. http://dx.doi.org/10.18011/bioeng2007v1n2p179-205.

Dalmago, G. A., Bergamaschi, H., Krüger, C. A. M. B., Bergonci, J. I., Comiran, F. \& Heckler, B. M. M. (2010). Evaporação da água na superfície do solo em sistemas de plantio direto e preparo convencional. Pesquisa Agropecuária Brasileira, 45(8), 780-790. https://doi.org/10.1590/S0100-204X2010000800002.

Daniel, D. F., Dallacort, R., Barbieri, J. D., Tieppo, R. C., Carvalho, M. A. C. de, Fenner, W., \& Yamashita, O. M. (2020). Evapotranspiração e produtividade de milho safrinha consorciado com crotalária. Research, Society and Development, 9(8), e890986196. https://doi.org/10.33448/rsd-v9i8.6196.

Demartelaere, A. C. F., Preston, W., Preston, H. A. F., Feitosa, S. S., Silva, T. B. M., Rodrigues, A. L. S., Ferreira, M. S., Silva, R. M., Rosado, A. K. H. B. \& Medeiros, D. C. (2020). Uso do hidrogel na família das aliaceas: Allium fistulosum e Allium cepa. Brazilian Journal of Development, 6(11), 90411-90420. https://doi.org/10.34117/bjdv6n11-450.

Empresa Brasileira de Pesquisa Agropecuária - EMBRAPA. (2013). Sistema brasileiro de classificação de solos. EMBRAPA.

Faria, R. T., Campeche, F. D. S. \& Chibana, E. Y. (2006). Construção e calibração de lisímetros de alta precisão. Revista Brasileira de Engenharia Agrícola e Ambiental, 10(1), 237-242. http://dx.doi.org/10.1590/S1415-43662006000100035.

Fenner, W., Dallacort, R., Faria Junior, C. A., Freitas, P. S. L., Queiroz, T. M. D. \& Santi, A. (2019). Development, calibration and validation of weighing lysimeters for measurement of evapotranspiration of crops. Revista Brasileira de Engenharia Agrícola e Ambiental, 23(4), 297-302. http://dx.doi.org/10.1590/1807-1929/agriambi.v23n4p297-302.

Filgueira, F. A.R. (2005). Novo Manual de olericultura: agrotecnologia moderna na produção e comercialização de hortaliças. UFV. 
Kang, Y. \& Wan, S. Effect of soil water potential on radish (Raphanus sativus L.) growth and water use under drip irrigation. Scientia Horticulturae, 106, 275-292. https://doi.org/10.1016/j.scienta.2005.03.012.

Lago, I., Streck, N. A., Bisognin, D. A., Souza, A. T. D. \& Silva, M. R. D. (2011). Transpiração e crescimento foliar de plantas de mandioca em resposta ao déficit hídrico no solo. Pesquisa Agropecuária Brasileira, 46(11), 1415-1423. https://doi.org/10.1590/S0100-204X2011001100001.

Linhares, P. C. F., Pereira, M. F. S., Oliveira, B. S., Henriques, G. P. S. A. \& Maracajá, P. B. (2010). Produtividade de rabanete em sistema orgânico de produção. Revista Verde de Agroecologia e Desenvolvimento Sustentável, 5(5), 94-101, 2010.

Moraes, O., Botrel, T. A. \& Dias, C. T. S. (2001). Efeito do uso de polímero hidroretentor no solo sobre o intervalo de irrig ação na cultura da alface (Lactuca sativa L.). Engenharia Rural, 12, 73-80.

Melo, R. A. C., Jorge, M. H. A., Bortolin, A., Boiteux, L. S., Ribeiro, C. \& Marconcini, J. M. (2019). Growth of tomato seedlings in substrates containing a nanocomposite hydrogel with calcium montmorillonite (NC-MMt). Horticultura Brasileira, 37(2), 199-203. https://doi.org/10.1590/ S0102-053620190210.

Mendonça, T. G., Urbano, V. R., Peres, J. G. \& Souza, C. F. (2013). Hidrogel como alternativa no aumento da capacidade de armazenamento de água no solo. Water Resources and Irrigation Management, 2(2), 87-92, 2013.

Namura, M., Pereira Filho, J. M., Costa, E. M., Pereira, L. S. \& Ventura, M. V. A. (2019). Avaliação de diferentes quantidades de hidrogel na produção de mudas de mamão papaya. Ipê Agronomic Journal, 3(1), 19-25. https://doi.org/10.37951/2595-6906.2019v3i1.4320.

Navroski, M. C., Araújo, M. M., Cunha, F. S., Berghetti, A. L. P. \& Pereira, M. O. (2014). Influência do polímero hidroretentor na sobrevivência de mudas de eucalyptus dunnii sob diferentes manejos hídricos. Nativa, 2(2), 108-113. https://doi.org/10.14583/2318-7670.v02n02a08.

Oliveira, G. Q., Biscaro, G. A., Motomiya, A. V. A., Jesus, M. P. \& Vieira Filho, P. S. (2014). Aspectos produtivos do rabanete em função da adubação nitrogenada com e sem hidrogel. Journal of Agronomic Sciences, 3(1), 89-100.

Oliveira, M. H. R. de, Sousa, A. E. C., Ávila, E. A. da S., Oliveira, R. S. de, Silva, R. M. da \& Ventura, M. V. A. (2020). Produtividade da cana-de-açúcar sob irrigação localizada: uma revisão sistemática. Research, Society and Development, 9(7), e104973966. https://doi.org/10.33448/rsd-v9i7.3966.

Rehman, A., Ahmad, R. \& Safdar, M. (2011). Effect of hydrogel on the performance of aerobic rice sown under different techniques. Plant, Soil and Environment, 57(7), 321-325, 2011.

Salomão, L. C. (2012). Calibração de tanques evaporímetros de baixo custo sob diferentes diâmetros em ambiente protegido. Tese doutorado, Universidade Estadual Paulista "Júlio De Mesquita Filho, UNESP, 74p.

Santos, H. T., Carvalho, D. F., Souza, C. F. \& Medici, L. O. (2015). Cultivo de alface em solos com hidrogel utilizando irrig ação automatizada. Engenharia Agrícola, 35(5), 852-862. https://doi.org/10.1590/1809-4430-eng.Agric.v35n5p852-862/2015.

Santos, R. D. S., Bispo, R. C., Ventura, K. M., Souza, M. H. C. \& Sales, M A. L. (2017). Avaliação de kit de irrigação por gotejamento utilizando água residuária. Irriga, Edição Especial (IRRIGA \& INOVAGRI), 110-117. https://doi.org/10.15809/irriga.2017v1n1p110-117.

Sayed, H., Kirkwood, R. C., Graham, N. B. (1991). The effects of a hydrogel polymer on the growth of certain horticultural crops under saline conditions. Journal of Experimental Botany, 42(240), 891-899.

Silva, F. de A. S. (2012). Assistat 7.6 beta. DEAG-CTRN.

Venturoli, F. \& Venturoli, S. (2011). Recuperação florestal em uma área degradada pela exploração de areia no Distrito Federal. Ateliê Geográfico, 5, 183195. https://doi.org/10.5216/ag.v5i1.13831.

Wallace, A. (1987). Anionic polyacrylamide treatment of soil improves seedling emergence and growth. Hortculture Science, 22, 951-960.

Willingham, J. \& Coffey, D. L. (1981). Influence of hydrophilic amended soil on growth of tomato transplants. Horticulture Science, 16(3), 289-298.

Yonezawa, U. G., Moura, M. R. \& Aouada, F. A. (2017). Bionanocompósitos híbridos formados por hidrogéis de polissacarídeo e nanoargila: II. Incorporação em substrato para melhoraria de mudas. Revista Cultura Agronômica, 26(1), 82-94. https://doi.org/10.32929/2446-8355.2017v26n1p82-94.

Zonta, J. H., Braun, H., Reis, E. F., Paulucio, D. \& Zonta, J. B. (2009). Influência de diferentes turnos de rega e doses de hidroabsorvente no desenvolvimento inicial da cultura do café conillon (Coffea canephora Pierre). IDESIA, 27(3), 29-34. 